\title{
Group II Metabotropic Glutamate Receptors Regulate the Vulnerability to Hypoxic Brain Damage
}

\author{
Alessandro Poli, ${ }^{1}$ Alina Beraudi, ${ }^{1}$ Luigi Villani, ${ }^{1}$ Marianna Storto, ${ }^{2}$ Giuseppe Battaglia, ${ }^{2}$ Valeria Di Giorgi Gerevini, ${ }^{3}$ \\ Irene Cappuccio, ${ }^{3}$ Andrea Caricasole, ${ }^{3,4}$ Mara D'Onofrio, ${ }^{2}$ and Ferdinando Nicoletti ${ }^{2,3}$ \\ ${ }^{1}$ Department of Biology, University of Bologna, 40126 Bologna, Italy, ${ }^{2}$ Istituto Neurologico Mediterraneo Neuromed, 86077 Pozzilli, Italy, ${ }^{3}$ Department of \\ Human Physiology and Pharmacology, University of Rome "La Sapienza," 00185 Rome, Italy, and ${ }^{4}$ SienaBiotech, 53100 Siena, Italy
}

We examined the expression of metabotropic glutamate (mGlu) receptors in species of fish that differ for their vulnerability to anoxic brain damage. Although expression of mGlula and mGlu5 receptors was similar in the brain of all species examined, expression of mGlu2/3 receptors was substantially higher in the brain of anoxia-tolerant species (i.e., the carp Carassius carassius and the goldfish Carassius auratus) than in the brain of species that are highly vulnerable to anoxic damage, such as the trouts Salmo trutta and Oncorhynchus mykiss. This difference was confirmed by measuring the mGlu2/3 receptor-mediated inhibition of forskolin-stimulated cAMP formation in slices prepared from the telencephalon of $C$. auratus and $S$. trutta. We exposed the goldfish C. auratus to water deprived of oxygen for $4 \mathrm{hr}$ for the induction of hypoxic brain damage. Although the goldfish survived this treatment, the occurrence of apoptotic cell death could be demonstrated by terminal deoxynucleotidyl transferase-mediated biotinylated UTP nick end labeling staining and by the assessment of caspase-3 activity in different brain region. The extent of cell death was highest in the medulla oblongata, followed by the optic tectum, cerebellum, and hypothalamus. No cell death was found in the telencephalon. This regional pattern of hypoxic damage was inversely related to the expression of mGlu2/3 receptors, which was lowest in the medulla oblongata and highest in the telencephalon. Treatment of the goldfish with the brain permeant mGlu2/3 receptor antagonist LY341495 (1 mg/kg, i.p.) amplified anoxic damage throughout the brain and enabled the induction of cell death by anoxia in the telencephalon. In contrast, treatment of the goldfish with the mGlu2/3 receptor agonist LY379268 ( 0.5 or $1 \mathrm{mg} / \mathrm{kg}$, i.p.) was highly protective against anoxic brain damage. Finally, exposure to the antagonist LY341495 $(0.5 \mu \mathrm{M})$ greatly amplified the release of glutamate induced by hypoxia in slices prepared from the medulla oblongata and the telencephalon of the goldfish. We conclude that expression of mGlu2/3 receptors provides a major defensive mechanism against brain damage in anoxia-tolerant species.

Key words: mGlu receptors; anoxia; apoptosis; goldfish; neuroprotection; glutamate release

\section{Introduction}

Metabotropic glutamate (mGlu) receptors have been implicated in mechanisms of neurodegeneration/neuroprotection and are considered as targets for neuroprotective drugs of potential use in the treatment of stroke or other neurodegenerative disorders (for review, see Nicoletti et al., 1996; Bruno et al., 2001a). However, the existence of eight mGlu receptor subtypes is a confounding factor in the search of novel neuroprotective strategies, and it is not clear which subtype (or group of subtypes) should be the preferential template for drug development. Selective mGlu1 receptor antagonists, such as the compounds AIDA, LY367385, CBPG, 3-MATIDA, and CPCCOEt, have shown neuroprotective activity in in vitro models of oxygen/glucose deprivation, as well as in gerbils subjected to transient global ischemia (Bruno et al., 1999; Pellegrini-Giampietro et al., 1999a,b; Meli et al., 2002; Moroni et al., 2002). These drugs might operate by removing the inhibitory control of mGlul receptors on GABA release

Received Nov. 25, 2002; revised April 14, 2003; accepted April 16, 2003.

Correspondence should be addressed to Dr. Ferdinando Nicoletti,Department of Human Physiology and Pharmacology, University of Rome "La Sapienza," Piazzale Aldo Moro, 5, 00185 Rome, Italy. E-mail: ferdinandonicoletti@hotmail.com. Copyright $\odot 2003$ Society for Neuroscience $\quad 0270-6474 / 03 / 236023-07 \$ 15.00 / 0$
(Pellegrini-Giampietro et al., 1999a,b; Battaglia et al., 2001). In one study (Rao et al., 2000), the mGlu5 receptor antagonist MPEP is shown to be more effective than AIDA in the gerbil model of global ischemia, although this is not confirmed by other studies (Meli et al., 2002). A potential drawback of mGlu5 receptor antagonists is that these drugs are expected to facilitate apoptosis by trophic deprivation (Copani et al., 1998), a process that contributes to the overall neuronal death in the ischemic brain (Lee et al., 1999). mGlu2/3 receptor agonists, such as 4-carboxy3-hydroxyphenylglycine or the novel compounds LY354740 and LY379268, are also neuroprotective in the gerbil model of global ischemia (Bond et al., 1998, 1999; Henrich-Noak et al., 1998) and in a neonatal rat model of hypoxia/ischemia (Cai et al., 1999), although an efficacy of these drugs in models of focal ischemia remains to be proven (for review, see Lam et al., 1998; Bond et al., 1999). The study of mGlu4/7/8 receptors in brain ischemia has been limited by the lack of systemically active drugs. However, mGlu4/7/8 receptor agonists are potential candidates for their ability to protect against excitotoxic neuronal death and to potently inhibit glutamate release (for review, see Bruno et al., 2001a). The choice of the appropriate target will be facilitated by studies aimed at establishing which mGlu receptor subtype spe- 
cifically regulates neuronal vulnerability to hypoxic/ischemic insults. This task can be accomplished by either using knock-out mice or by examining the expression and function of mGlu receptor subtypes in animal species that differ for their vulnerability to brain anoxia or ischemia. Fish offer a powerful model to address this issue because some species (such as the goldfish Carassius auratus and the carp Carassius carassius) show an unusually high resistance to hypoxic brain damage (Holopainen et al., 1986; Lutz et al., 1996). Nearly all mGlu receptor subtypes have been detected in the fish brain by studies combining RT-PCR analysis, immunoblotting, immunocytochemistry, and biochemical or electrophysiological assessment of receptor function (Cochilla and Alford, 1998; Medler et al., 1998; Gafka et al., 1999; Linn and Gafka, 1999; Poli et al., 1999; Yamada et al., 1999; Zhang and Schmidt, 1999; Linn, 2000; Shiells and Falk, 2000; Hirasawa et al., 2002; Krieger and El Manira, 2002). Using the goldfish C. auratus we now show that the expression of $\mathrm{mGlu} 2 / 3$ receptors is a critical determinant of brain vulnerability to anoxic damage.

\section{Materials and Methods}

Drugs. 2R,4R-4-Aminopyrrolidine-2,4-dicarboxylate (2R,4R-APDC) and 2S-2-amino-2-(1S,2S-2-carboxycyclopropan-1-yl)-3-(xamth-9-yl)propionate (LY341495) were purchased from Tocris Cookson Ltd.. (-)-2-Oxa-4aminobicyclo[3.1.0] hexane-4,6-dicarboxylate (LY379268) was kindly provided by Lilly Research Laboratories (Indianapolis, IN). All other drugs were purchased from Sigma-Aldrich (Milan, Italy).

Western blot analysis. The crucian carp C. carassius, the goldfish C. auratus, the trouts Salmo trutta and Oncorhynchus mykiss, the fish Cottus gobio, and the catfish Liposarcus anisitsi were provided by a local breeder. For Western blot analysis, fish were killed by decapitation, brain were excised by cutting the border between the vagal lobe and the spinal cord, and whole brain extracts were used for the detection of mGlu receptors. The brain of the goldfish $C$. auratus was dissected out into the following regions: telencephalon, optic tectum, hypothalamus, cerebellum, and medulla oblongata. The cerebral cortex and cerebellum of male Sprague Dawley rats (150-200 gm, body weight; Charles River, Calco, Italy) were used as reference tissues for immunoblots. Tissue was either used fresh or stored at $-80^{\circ} \mathrm{C}$ until use. Western blot analysis of mGlu1a, mGlu5, and mGlu2/3 receptors was performed as described previously (Poli et al., 1999). Immunostaining was revealed using the ECL Western blotting analysis system (Amersham). Polyclonal antibodies specific for mGlula, mGlu2/3, and mGlu5 receptors (all at $1 \mu \mathrm{g} / \mathrm{ml}$ ) were purchased from Upstate Biotechnology (Lake Placid, NY).

Measurements of cAMP and glutamate release in brain slices. Experiments were performed using $350 \times 350 \mu \mathrm{m}$ slices prepared from the telencephalon of $C$. auratus and $S$. trutta (for measurements of cAMP) and from the telencephalon and medulla oblongata of C. auratus (for the assessment of glutamate release) using a McIlwain tissue chopper. In some experiments, we assessed cell viability in C. auratus and S. trutta slices by determining ATP, ADP, and AMP levels and calculating the energy charge as (ATP + 1/2 ADP)/(ATP + ADP + AMP), as described by Poli et al. (1997). Energy charge was always $>0.83$, indicating that energy metabolism was largely preserved in our preparations. For cAMP experiments, slices were preincubated for $30 \mathrm{~min}$ in Krebs-Henseleit buffer (120 mM NaCl, $10 \mathrm{~mm} \mathrm{KCl,} 10 \mathrm{~mm}$ glucose, $1.2 \mathrm{~mm} \mathrm{MgCl}_{2}$, and 1.3 $\mathrm{mM} \mathrm{CaCl}_{2}$, equilibrated with $95 \% \mathrm{O}_{2} / 5 \% \mathrm{CO}_{2}$ to $\mathrm{pH}$ 7.4) and then stimulated with $10 \mu \mathrm{M}$ forskolin for $15 \mathrm{~min}$ in the presence of IBMX $(0.5 \mathrm{mM}$, applied $20 \mathrm{~min}$ before forskolin). When present, 2R,4R-APDC was applied $2 \mathrm{~min}$ before forskolin. The reaction was terminated by the addition of $0.4 \mathrm{M}$ perchloric acid, followed by sonication and storage at $-80^{\circ} \mathrm{C}$. After neutralization with $\mathrm{K}_{2} \mathrm{CO}_{3}$, cAMP levels were determined by RIA using a commercially available kit (Amersham Pharmacia Biotech Italia, Cologno Monzese, Italy).

To examine the release of glutamate, slices from the medulla oblongata and the telencephalon of $C$. auratus were plated over a paper filter disk in a perfusion apparatus, as described by Lucchi et al. (1994). Slices were perfused for 60 min with Krebs phosphate buffer ( $\mathrm{pH} 7.4$ ), continuously oxygenated at $22^{\circ} \mathrm{C}$, at a rate of $0.5 \mathrm{ml} / \mathrm{min}$. At the end of the $60-\mathrm{min}$ period, two 2-min fractions were collected for measurements of basal release. The medium was then changed with the new medium continuously bubbled with $\mathrm{N}_{2}$ for the induction of hypoxia, and four additional 2-min fractions were collected. When required, LY341495 was continuously present in the medium, starting from 5 min before the onset of hypoxia. Analysis of glutamate in the perfusate was performed by precolumn derivatization with $o$-phthalaldehyde and mercaptoethanol, followed by HPLC with fluorescence detection. One hundred-microliter sample aliquots were diluted with $0.1 \mathrm{~N} \mathrm{HCl}$ and mixed with equal volumes of fluorescent reagent. The mixture was kept at room temperature for $1 \mathrm{~min}$ to derivatize the sample before being injected into the column by a $200 \mathrm{ml}$ loop. The system used an autosampler 507 (Beckman Instruments, Fullerton, CA), a programmable solvent module 126 (Beckman Instruments), an analytical reverse phase $\mathrm{C}-18$ column at $30^{\circ} \mathrm{C}$ (Ultrasphere ODS $3 \mathrm{~mm}$ spherical, $80 \AA$ pore, $250 \mathrm{~mm}$; Beckman Instruments), an RF-551 spectrofluorimetric detector (Shimadzu, Tokyo, Japan), and a computer running a Gold Nouveau software (Beckman Instruments). The excitation and emission wavelengths were set at $360 \mathrm{~nm}$ and $450 \mathrm{~nm}$, respectively. The mobile phase consisted of (A) $50 \mathrm{~mm}$ sodium phosphate, $\mathrm{pH} 7.2$, containing 10\% methanol, and (B) $50 \mathrm{~mm}$ sodium phosphate, $\mathrm{pH} 7.2$, containing $70 \%$ methanol, at a flow rate of $0.3 \mathrm{ml} / \mathrm{min}$. Both buffers were filtered through a $0.45 \mathrm{~mm}$ filter and degassed under vacuum for $5 \mathrm{~min}$. Gradient elution consisted of $98 \% \mathrm{~A}$ and $2 \%$ B initially for $16 \mathrm{~min}$, was then increased to $98 \%$ B over $1 \mathrm{~min}$, maintained for 12 min to elute other substances, and then returned to the initial conditions before running the next sample.

Induction of anoxic brain damage in the goldfish. Goldfish $(10-12 \mathrm{~cm}$ in length; $35 \mathrm{gm}$, body weight) were maintained at $22^{\circ} \mathrm{C}$ in thermostated glass aquariums filled with unchlorinated water constantly aerated and filtered through activated charcoal filters for 15 days. Control fish were then transferred to an aquarium (10 l) that was continuously aerated and kept there for $4 \mathrm{hr}$. Another group of fish was maintained for $4 \mathrm{hr}$ in an aquarium (101) in which the water was continuously bubbled with $\mathrm{N}_{2}$ for the induction of anoxia. Separate groups of control or anoxic fish were treated with LY341495 (1 mg/kg, i.p.) or LY379268 (0.5 mg/kg, i.p.), 30 min before being placed in the control or anoxic aquarium. At the end of the 4 -hr period, all fish were transferred to an aerated aquarium, and, 48 $\mathrm{hr}$ later, they were killed for the assessment of apoptotic cell death.

Terminal deoxynucleotidyl transferase-mediated biotinylated UTP nick end labeling staining. The brains were fixed in a solution of $4 \%$ paraformaldheyde in $0.1 \mathrm{M}$ PBS, $\mathrm{pH} 7.4$, for $5 \mathrm{hr}$ at $4^{\circ} \mathrm{C}$ and cryoprotected in $20 \%$ sucrose in $0.1 \mathrm{~m}$ PBS, pH 7.4, for $48 \mathrm{hr}$. Twenty-micrometer cryostat sections were mounted on precoated slides and stained with the terminal deoxynucleotidyl transferase-mediated biotinylated UTP nick end labeling (TUNEL) method (Roche; In situ cell death detection POD, 1684817). TUNEL-stained sections were examined under an Olympus BH-2 microscope, and apoptotic cells were counted in the medulla oblongata, optic tectum, cerebellum, hypothalamus, and telencephalon.

Caspase-3 activity assay. Goldfish brain regions (medulla oblongata and telencephalon) were dissected on ice, immediately rinsed with icecold PBS, and then transferred to the lysis buffer of the Caspase Activity Assay kits (Chemicon International). Samples were first homogenized (Teflon/glass), sonicated for $40 \mathrm{sec}$, and then centrifuged at 14,000 rpm for $20 \mathrm{~min}$. The supernatant was centrifuged again at $14,000 \mathrm{rpm}$, and the resulting supernatant was used for the assay. The assay, based on the colorimetric detection ( $405 \mathrm{~nm}$ ) of $p$-nitroanilide (pNA) originated from the cleavage of the peptide substrate DEVD-pNA, was performed according to the manufacturer's suggestions in 96-well microplates. The reaction mixture contained $4.3 \mathrm{~mm}$ DTT. The kinetics of the reaction was monitored at different time intervals by means of a microplate reader (Minireader II; Dynatech, Alexandria, VA).

\section{Results}

We examined the expression of mGlu2/3 receptors in fish species that differ for their vulnerability to hypoxic damage. The crucian carp C. carassius and the goldfish C. auratus were selected as anoxia-tolerant species, whereas the trouts $S$. trutta and $O$. 


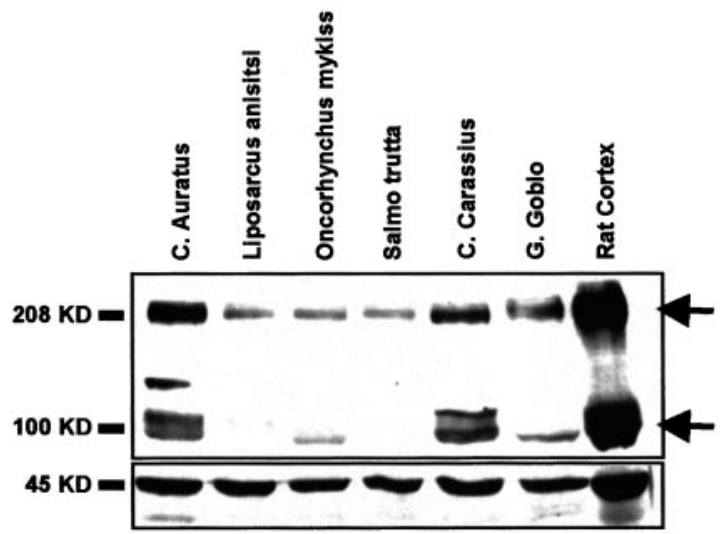

Figure 1. Western blot analysis of mGlu2/3 receptors in whole brain extracts from anoxiatolerant and anoxia vulnerable fish. Fifty micrograms of proteins were loaded per lane. The rat cerebral cortex is shown as a positive control. The bands at $100 \mathrm{kDa}$ represent receptor monomers. The top band ( $208 \mathrm{kDa}$ ) may correspond to receptor dimers. The $\beta$-actin band is shown below ( $45 \mathrm{kDa}$ ). This blot was repeated three times with identical results.

mykiss, and the fish C. gobio were selected as examples of anoxiaintolerant species. The catfish $L$. anisitsi is relatively tolerant to anoxia, but this is because of the presence of an accessory air breathing mechanism (de Oliveira et al., 2001). In the rat cerebral cortex (used as a positive control), $\mathrm{mGlu} 2 / 3$ receptor antibodies labeled two bands at $\sim 100 \mathrm{kDa}$, which may correspond to mGlu2 and mGlu3 receptor monomers, and an additional high molecular weight band, which corresponds to receptor dimers. When examined in whole brain preparations, $\mathrm{mGlu} 2 / 3$ receptors were expressed by all species of fish. However, expression was much greater in the brain of C. carassius and C. auratus than in the brain of all other species. Interestingly, the carp and the goldfish were the only two species in which two $100 \mathrm{kDa}$ immunoreactive bands were present. The goldfish also showed an additional band at $\sim 140 \mathrm{kDa}$, the identity of which is unknown (Fig. 1). To examine whether the greater expression of $\mathrm{mGlu} 2 / 3$ receptors was accounted for by a greater number of functional receptors rather than by an increased receptor reserve, we measured the inhibition of forskolin-stimulated cAMP formation by the selective mGlu $2 / 3$ receptor agonist $2 \mathrm{R}, 4 \mathrm{R}-\mathrm{APDC}$, in slices prepared from the telencephalon of $S$. trutta and C. auratus. The efficacy of 2R,4R-APDC was greater in slices from C. auratus (63\% of maximal inhibition of forskolin-stimulated cAMP formation vs $44 \%$ in S. trutta), indicating a greater number of functional mGlu2/3 receptors (Fig. 2). We also examined the expression of mGlu1 and mGlu5 receptors in whole brain extracts from the two Carassius species and from S. trutta and O. mykis. Expression of mGlu5 receptors was light and did not differ among all species, whereas expression of mGlul receptors was virtually undetectable (data not shown).

To examine whether mGlu2/3 receptors could be an important determinant to anoxia tolerance, we studied the regional distribution of anoxic brain damage in the goldfish C. auratus, as related to the distribution pattern of $m$ Glu $2 / 3$ receptors. Anoxic damage was induced by replacing the aerated water with $\mathrm{N}_{2}$ bubbled water. The percentage of $\mathrm{O}_{2}$ in the water after 30 min of $\mathrm{N}_{2}$ bubbling ranged from $0.2 \%$ to $0.6 \%$, corresponding to a $\mathrm{pO}_{2}$ value of $1.52-4.56 \mathrm{mmHg}$. Four hours of anoxia induced the development of apoptotic cell death, as assessed $48 \mathrm{hr}$ later by the TUNEL staining (shown in Fig. 3). The extent of apoptotic death was greater in the medulla oblongata, followed by the optic tec-

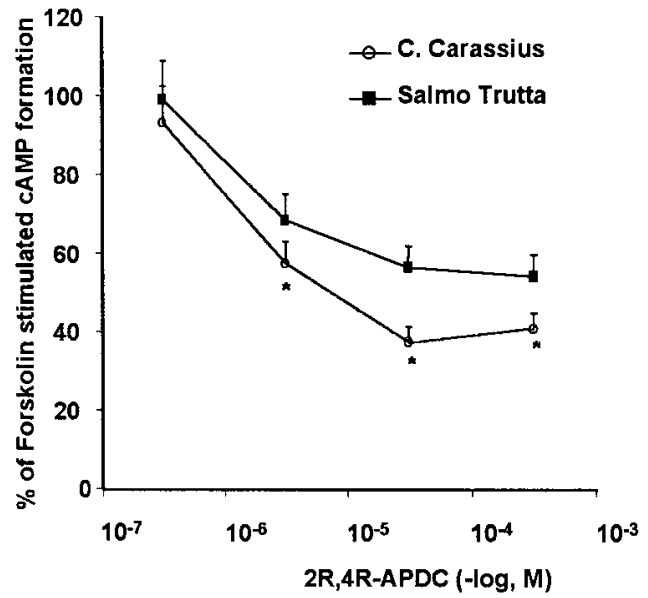

Figure 2. Concentration-dependent inhibition of forskolin-stimulated CAMP formation by 2R,4R-APDC in slices prepared from the telencephalon of the goldfish C. auratus and the trout $S$. trutta. Values are means + SEM of five determinations. ${ }^{*} p<0.05$ (Student's $t$ test) versus the corresponding values of $S$. trutta.

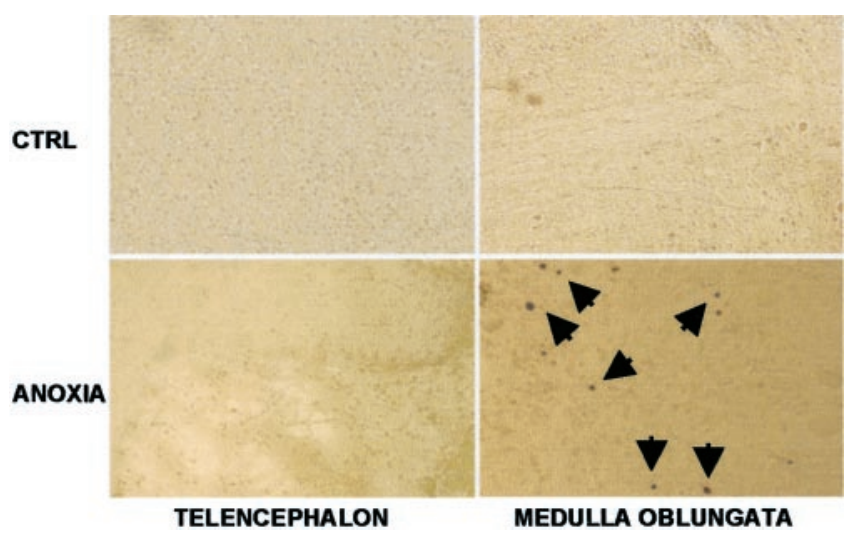

Figure 3. TUNEL staining in the telencephalon and medulla oblongata from control or anoxic goldfish. Goldfish were killed after $4 \mathrm{hr}$ of anoxia (see Materials and Methods). TUNEL-positive cells are indicated by the arrows. Note the absence of apoptotic death in the telencephalon.

tum, cerebellum, and hypothalamus. No TUNEL-positive cells were found in the telencephalon of anoxic goldfish (Figs. 3, 4). To further support the apoptotic nature of cell death, we measured caspase- 3 activity in lysates from the medulla oblongata and telencephalon of the goldfish. Consistent with TUNEL data, $4 \mathrm{hr}$ of anoxia increased caspase- 3 activity by about twofold in the medulla oblongata without inducing detectable changes in the telencephalon (Fig. 5). The regional pattern of cell death showed a strong inverse correlation $(r=0.97 ; p<0.01)$ with the expression of $\mathrm{mGlu} 2 / 3$ receptors, which was highest in the telencephalon and lowest in the medulla oblongata, with intermediary levels found in the hypothalamus, cerebellum, and optic tectum (Fig. $6 A, B)$. We next examined whether pharmacological activation or inhibition of $\mathrm{mGlu} 2 / 3$ receptors could affect anoxic cell death in the goldfish. We addressed this issue by using the compounds LY379268 and LY341495, which can cross the blood brain barrier and are, therefore, suitable for systemic administration. LY379268 selectively activates mGlu2/3 receptors with a potency in the low nanomolar range. LY341495 antagonizes mGlu2/3 receptors at nanomolar concentrations, although it can recruit additional mGlu receptor subtypes at high concentrations (for re- 

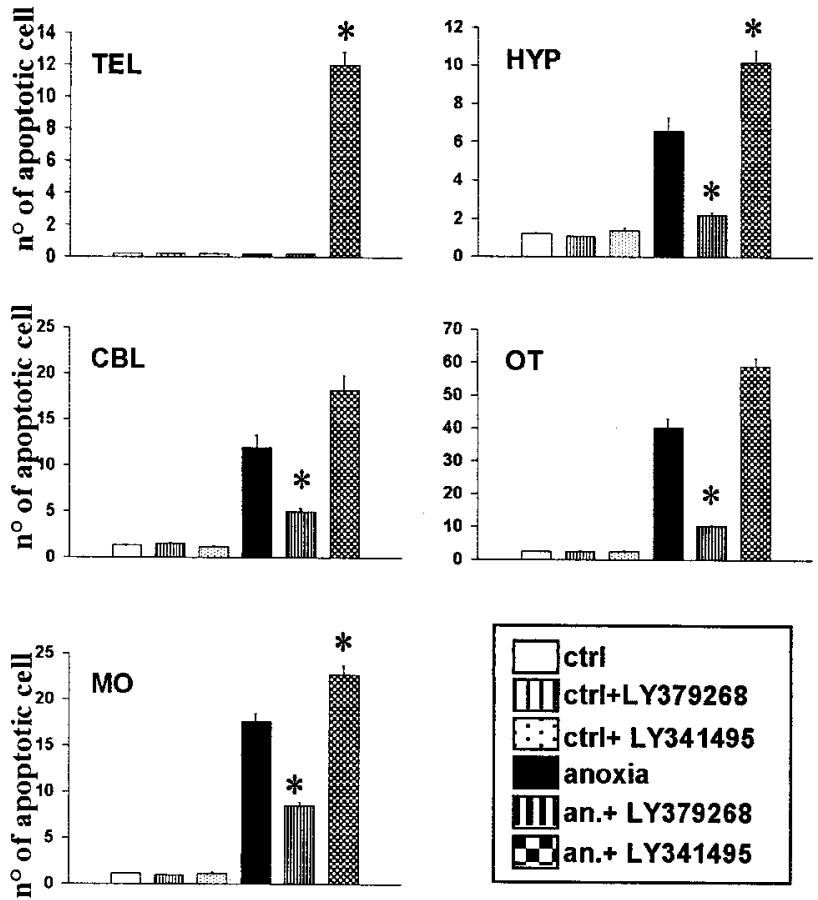

Figure 4. Anoxia-induced apoptotic cell death in different brain regions of the goldfish. The number of apoptotic cells was scored from four microscopic fields ( $r=200 \mu \mathrm{m}$ per field; magnification, $400 \times$ ) by an observer who was unaware of the treatment. LY379268 (0.5 mg/ kg, i.p.) and LY341495 (1 mg/kg, i.p.) were injected intraperitoneally $30 \mathrm{~min}$ before the onset of anoxia. Values are means + SEM of five individual determinations. ${ }^{*} p<0.05$ versus anoxia (one-way ANOVA plus Fisher's PLSD). HYP, Hypothalamus; TEL, telencephalon; OT, optic tectum; $\mathrm{CBL}$, cerebellum; $\mathrm{MO}$, medulla oblongata.
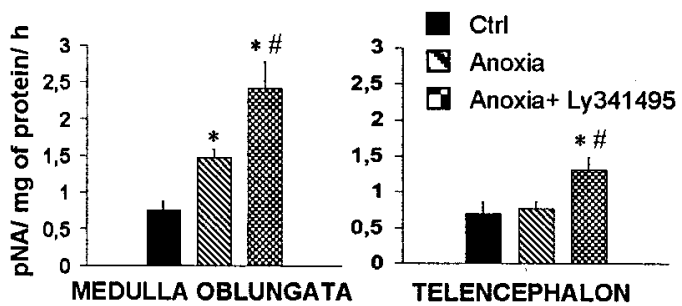

Figure 5. Caspase-3 activity in the medulla oblongata and telencephalon of goldfish subjected to $4 \mathrm{hr}$ of anoxia with or without LY341495 treatment $(1 \mathrm{mg} / \mathrm{kg}$, i.p, $30 \mathrm{~min}$ before anoxia). Values are means + SEM of 5-10 individual determinations. $p<0.05$ (one-way ANOVA plus Fisher's PLSD), as compared with controls (Ctrl) $\left(^{*}\right)$ or with anoxia alone (\#).

view, see Schoepp et al., 1999). The activity of these two drugs was confirmed by measuring forskolin-stmulated cAMP formation in slices from the telencephalon of the goldfish (data not shown). Injection of LY341495 (1 mg/kg, i.p., $30 \mathrm{~min}$ before the onset of anoxia) amplified anoxia-induced cell death in all brain regions of the goldfish. This effect was remarkable in the telencephalon, in which cell death could only be observed in anoxic goldfish treated with LY451495 (Figs. 4, 5). Systemic injection of the agonist LY379268 (0.5 mg/kg, i.p., $30 \mathrm{~min}$ before the onset of anoxia) partially protected against anoxia-induced cell death (from $55 \%$ to $82 \%$ of protection in the various brain regions) (Fig. 4). The extent of protection was similar when the dose of LY379268 was raised to $1 \mathrm{mg} / \mathrm{kg}$, i.p. $(55+6.2 \%$ in the optic tectum; $71+8.9 \%$ in the medulla oblongata; and $57+4.6 \%$ in the cerebellum).

Finally, we examined the stimulation of glutamate release in
A)

B)
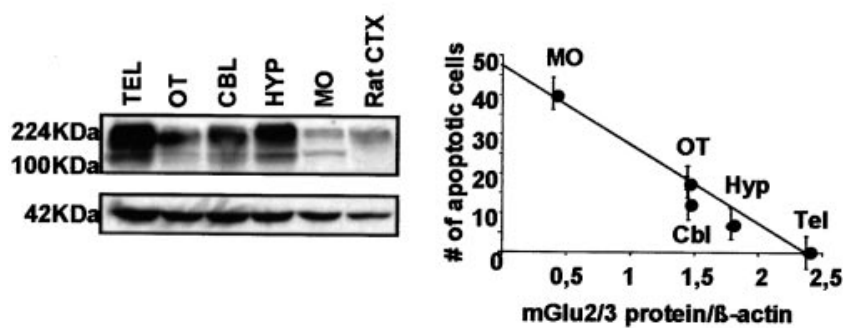

Figure 6. A, Representative immunoblot of $\mathrm{mGlu2} / 3$ receptors in different regions from the goldfish brain. Fifty micrograms of proteins were loaded per lane, except for the last lane (rat (TX), in which $20 \mu \mathrm{g}$ of proteins was loaded. The $\beta$-actin band is shown in the lower part of the blot. $B$, Inverse correlation between $\mathrm{mGlu} 2 / 3$ receptor expression (normalized by $\beta$-actin) and the extent of apoptotic cell death determined after $4 \mathrm{hr}$ of anoxia (see Fig. 4).

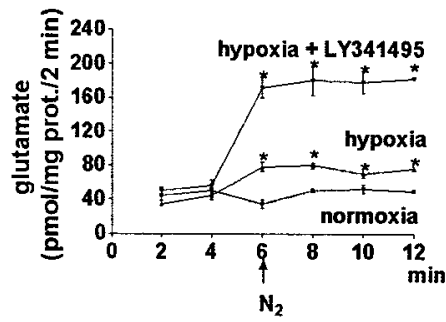

MEDULLA OBLUNGATA

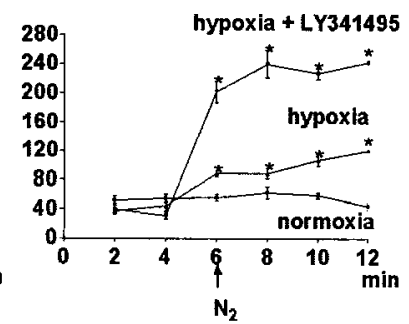

TELENCEPHALON

Figure 7. Hypoxia-induced glutamate release in slices prepared from the medulla oblongata or the telencephalon of the goldfish. Two-minute fractions were collected for measurements of extracellular glutamate. Arrows indicate the onset of hypoxia. When present, LY341495 (0.5 $\mu \mathrm{m})$ was added to the perfusate $5 \mathrm{~min}$ before the onset of hypoxia. Thus, fractions collected at 2 and 4 min show that LY341495 fails to affect glutamate release in the absence of hypoxia. Values are means + SEM of four individual determinations. ${ }^{*} p<0.01$ (one-way ANOVA plus Fisher's PLSD) versus the respective normoxic values.

slices prepared from the medulla oblongata and telencephalon of the goldfish. Slices continuously perfused with oxygenated buffer released an average of $40-50 \mathrm{pmol} / \mathrm{mg}$ protein per $2 \mathrm{~min}$. Release remained unchanged with time (see "normoxia" in Fig. 7). Substitution of the medium with a hypoxic medium led to a significant, albeit slight, increase in glutamate release. LY341495 (0.5 $\mu \mathrm{M}$ ) applied to the perfusate $1 \mathrm{~min}$ before the collection of the first fraction did not affect per se glutamate release (see first two fractions). However, the combination of hypoxia plus LY341495 induced a substantial increase in glutamate release. This increase was higher in slices from the telencephalon, in which glutamate levels were more than sixfold greater than basal levels (Fig. 7).

\section{Discussion}

The crucian carp C. carassius and the goldfish C. auratus share with freshwater turtles an abnormally high tolerance to brain anoxia (Holopainen et al., 1986; Lutz, 1992; Lutz et al., 1996). A number of factors, including large glycogen stores, increased blood supply to the brain, downregulation of excitatory ion conductance, and upregulation of inhibitory neuroreceptors, may contribute to brain tolerance to anoxia (Nilsson et al., 1993; Johansson and Nilsson, 1995; Lutz et al., 1996; Smith et al., 1996). Taken collectively, our data strongly suggest that a high expression of $\mathrm{mGlu} 2 / 3$ receptors provides a major defensive mechanism against anoxic cell death in the crucian carp and the gold- 
fish. The catfish did not show high levels of mGlu2/3 receptors, but it cannot be defined as an anoxia-tolerant species because its resistance to anoxia depends on alternative breathing systems and, particularly, on its capacity to retain air in the stomach (de Oliveira et al., 2001). mGlu2/3 receptors are coupled to Gi proteins, and their activation inhibits cAMP formation in heterologous expression systems (for review, see Pin and Duvoisin, 1995). However, native mGlu2/3 receptors can also negatively modulate a variety of voltage-sensitive $\mathrm{Ca}^{2+}$ channels and stimulate the MAP kinase and phosphatidylinositol-3-kinase pathways (for review, see De Blasi et al., 2001). Activation of mGlu2/3 receptors inhibits glutamate release and depresses excitatory postsynaptic currents (for review, see Pin and Duvoisin, 1995). This function, which is conserved in the fish brain (Cochilla and Alford, 1998; Poli et al., 1999), could be related to a protective activity of mGlu2/3 receptors against anoxic damage. Using slices prepared from the medulla oblongata or the telencephalon of the goldfish, we found that hypoxia was associated with a slight, but consistent, increase in glutamate release. Interestingly, this increase was greatly amplified when hypoxia was induced in slices treated with $0.5 \mu \mathrm{M}$ LY341495. At these concentrations, LY341495 selectively antagonizes mGlu2 and mGlu3 receptors, although it can also recruit mGlu8 receptors (Schoepp et al., 1999). Amplification of hypoxia-induced glutamate release by LY341495 was greater in slices from the telencephalon than in slices from the medulla oblongata. This paralleled the expression levels of mGlu2/3 receptors, which was also greater in the telencephalon. On the basis of these findings, we speculate that activation of $\mathrm{mGlu} 2 / 3$ receptors provides a major defense against anoxic damage by limiting the extent of pathological glutamate release in the goldfish brain. The high expression of $\mathrm{mGlu} 2 / 3$ receptor might contribute to explain why glutamate is not released in the telencephalon of the crucian carp during anoxia (Hylland and Nilsson, 1999). The amount of extracellular glutamate normally found in the brain of the crucian carp ( $~ 30 \mu \mathrm{M}$; Hylland and Nilsson, 1999) should be sufficient to activate mGlu $2 / 3$ receptors, and to prevent glutamate release during anoxia. Other inhibitory receptors, such as A1 adenosine receptors, might behave similarly to mGlu2/3 receptors (Rosati et al., 1995; Hylland and Nilsson, 1999). Protection against anoxic damage could also be explained by mechanisms mediated by postsynaptic mGlu2 or mGlu3 receptors (for review, see Tamaru et al., 2001), such as the inhibition of membrane excitability resulting from a reduction of cAMP formation or by a G-protein-dependent modulation of ion channels. In addition, activation of mGlu 3 receptors present in glial cells may contribute to neuroprotection by enhancing the production of TGF- $\beta$, which is known to protect neurons against excitotoxic death (Bruno et al., 1998; D’Onofrio et al., 2001). Thus, mGlu2/3 receptors cater the potential to behave as a major defensive mechanism in anoxia-tolerant species. It is particularly relevant that the brain of the carp and the goldfish expressed small amounts of mGlu1a and mGlu5 receptors (for review, see Poli et al., 1999), which both play a permissive role in the induction of excitotoxic neuronal death (for review, see Bruno et al., 2001b). The use of the goldfish for the study of anoxic brain damage was particularly advantageous because this species is tolerant to anoxia, but to a lesser extent than the crucian carp. Thus, a 4-hr exposure to anoxia induced apoptotic cell death in the goldfish brain, which could be quantified by the TUNEL staining. Interestingly, there was a high degree of inverse correlation between the regional pattern of cell death and the expression profile of $m G l u 2 / 3$ receptors. This provides the first evidence that the expression of any mGlu receptor subtype significantly correlates with the extent of neuronal death and suggests that the amount of mGlu2/3 receptors critically regulates neuronal vulnerability to hypoxic insult. This hypothesis was strengthened by the use of compounds LY379268 and LY341495, which are systemically active (Ornstein et al., 1998; Monn et al., 1999) and could, therefore, be injected intraperitoneally before the onset of anoxia. LY379268 behaves as a highly potent $\mathrm{mGlu} 2 / 3$ receptor agonist, with an affinity in the low nanomolar range (Monn et al., 1999); LY341495 antagonizes mGlu2/3 receptors at nanomolar concentrations, although it can also recruit other mGlu receptor subtypes at higher concentrations (Kingston et al., 1998; Ornstein et al., 1998; Johnson et al., 1999). We used doses of LY341495 (1 mg/kg, i.p.) that can be considered as highly preferential for $\mathrm{mGlu} 2 / 3$ receptors. Systemic administration of LY341495 uniformly amplified anoxic cell death in the goldfish brain. Remarkably, anoxia could induce cell death in the telencephalon only in goldfish treated with LY341495, confirming the hypothesis that a high density of functional $\mathrm{mGlu} 2 / 3$ receptors is a major determinant of anoxic tolerance. The widespread protective activity of the agonist LY379268 further supports the protective role of $\mathrm{mGlu} 2 / 3$ receptors and suggests that these receptors are not saturated by the endogenous glutamate under anoxic conditions. However, the different vulnerability of the various goldfish brain regions to anoxia cannot be entirely explained by the different expression levels and/or extent of activation of $\mathrm{mGlu} 2 / 3$ receptors, because we still observed an incomplete (albeit substantial) protection when we doubled the doses of systemically injected LY379268.

The possibility that the expression of $\mathrm{mGlu} 2 / 3$ receptors sets the threshold for hypoxic neuronal damage also in higher vertebrates is particularly attractive because drugs have been described that selectively upregulate group II mGlu receptors in the rodent brain (Chiechio et al., 2002). According to the excitotoxic hypothesis of ischemic brain damage (Choi, 1988; Choi and Rothman, 1990), different levels of expression or activity of ionotropic glutamate receptors may contribute to explain the selective neuronal vulnerability observed in response to transient ischemia (Collins et al., 1989; Koh et al., 1996). It is noteworthy that mGlu3 receptors show a higher expression in the relatively resistant hippocampal dentate gyrus than in the highly vulnerable CA1 region (Tamura et al., 2001). It will be interesting to examine whether induced changes in the expression of group II mGlu receptors modify the intrinsic vulnerability of selected neuronal population to hypoxic/ischemic damage.

\section{References}

Battaglia G, Bruno V, Pisani A, Centonze D, Catania MV, Calabresi P, Nicoletti F (2001) Selective blockade of type-1 metabotropic glutamate receptors induces neuroprotection by enhancing gabaergic transmission. Mol Cell Neurosci 17:1071-1083.

Bond A, O’Neill MJ, Hicks CA, Monn JA, Lodge D (1998) Neuroprotective effects of a systemically active group II metabotropic glutamate receptor agonist LY354740 in a gerbil model of global ischaemia. NeuroReport 9:1191-1193.

Bond A, Rogumoorthy N, Monn JA, Hicks CA, Ward MA, Lodge D, O’Neill MJ (1999) LY379268, a potent and selective group II metabotropic glutamate receptor agonist, is neuroprotective in gerbil global, but not focal, cerebral ischaemia. Neurosci Lett 273:191-194.

Bruno V, Battaglia G, Casabona G, Copani A, Caciagli F, Nicoletti F (1998) Neuroprotection by glial metabotropic glutamate receptors is mediated by transforming growth factor- $\beta$. J Neurosci 18:9594-9600.

Bruno V, Battaglia G, Kingston A, O’Neill MJ, Catania MV, Di Grazia R, Nicoletti F (1999) Neuroprotective activity of the potent and selective mGlula metabotropic glutamate receptor antagonist, (+)-2-methyl-4 carboxyphenylglycine (LY367385): comparison with LY357366, a broader spectrum antagonist with equal affinity for mGlula and mGlu5 receptors. Neuropharmacology 38:199-207. 
Bruno V, Battaglia G, Copani A, D’Onofrio M, Di Iorio P, De Blasi A, Melchiorri D, Flor PJ, Nicoletti F (2001a) Metabotropic glutamate receptor subtypes as targets for neuroprotective drugs. J Cereb Blood Flow Metab 21:1013-1033.

Bruno V, Battaglia G, Copani A, Cespedes VM, Galindo MF, Cena V, Sanchez-Prieto J, Gasparini F, Kuhn R, Flor PJ, Nicoletti F (2001b) An activity-dependent switch from facilitation to inhibition in the control of excitotoxicity by group I metabotropic glutamate receptors. Eur J Neurosci 13:1469-1478.

Cai Z, Xiao F, Lee B, Paul IA, Rhodes PG (1999) Prenatal hypoxia-ischemia alters expression and activity of nitric oxide synthase in the young rat brain and causes learning deficits. Brain Res Bull 15:359-366.

Chiechio S, Caricasole A, Storto M, Catania MV, Copani A, Vertechi M, Nicolai R, Calvani M, Melchiorri D, Nicoletti F (2002) L-Acetylcarnitine induces analgesia by selectively up-regulating mGlu2 metrabotropic glutamate receptors. Mol Pharmacol 61:989-996.

Choi DW (1988) Calcium-mediated excitotoxicity: relationship to specific channel types and role in ischemica damage. Trends Neurosci 11:465-469.

Choi DW, Rothman SM (1990) The role of glutamate neurotoxicity in hypoxic-ischemic neuronal death. Annu Rev Neurosci 13:171-182.

Cochilla AJ, Alford S (1998) Metabotropic glutamate receptor-mediated control of neurotransmitter release. Neuron 20:1007-1016.

Collins RC, Dobkin BH, Choi DW (1989) Selective vulnerability of the brain: new insights into the pathophysiology of stroke. Ann Intern Med 110:992-1000.

Copani A, Casabona G, Bruno V, Caruso A, Condorelli DF, Messina A, Di Giorgi Gerevini V, Pin JP, Kuhn R, Knopfel T, Nicoletti F (1998) The metabotropic glutamate receptor mGlu5 controls the onset of developmental apoptosis in cultured cerebellar neurons. Eur J Neurosci 10:2173-2184.

De Blasi A, Conn PJ, Pin J, Nicoletti F (2001) Molecular determinants of metabotropic glutamate receptor signaling. Trends Pharmacol Sci 22:114-120.

de Oliveira C, Taboga SR, Smarra AL, Bonilla-Rodrigues GO (2001) Microscopical aspects of accessory air breathing through a modified stomach in the armoured catfish Liposarcus anisitsi (Siluriformes, Loricariidae). Cytobios 105:153-162.

D’Onofrio M, Cuomo L, Battaglia G, Ngomba RT, Storto M, Kingston AE, Orzi F, De Blasi A, Di Iorio P, Nicoletti F, Bruno V (2001) Neuroprotection mediated by glial group-II metabotropic glutamate receptors requires the activation of the MAP kinase and the phosphatidylinositol-3kinase pathways. J Neurochem 78:435-445.

Gafka AC, Vogel KS, Linn CL (1999) Evidence of metabotropic glutamate receptor subtypes found on catfish horizontal and bipolar retinal neurons. Neuroscience 90:1403-1414.

Henrich-Noack P, Hatton CD, Reymann KG (1998) The mGlu receptor ligand (S)-4C3HPG protects neurons after global ischaemia in gerbils. NeuroReport 20:985-988.

Hirasawa H, Shiells R, Yamada M (2002) A metabotropic glutamate receptor regulates transmitter release from cone presynaptic terminals in carp retinal slices. J Gen Physiol 119:55-68.

Holopainen IJ, Hyvarinen H, Piironen J (1986) Anaerobic wintering of crucian carp (Carassius carassius L.)-II. Metabolic products. Comp Biochem Physiol A 83:239-242.

Hylland P, Nilsson GE (1999) Extracellular levels of amino acid neurotransmitter during anoxia and forced energy deficiency in crucian carp brain. Brain Res 823:49-58.

Johansson D, Nilsson G (1995) Roles of energy status, KATP channels and channel arrest in fish brain $\mathrm{K}^{+}$gradient dissipation during anoxia. J Exp Biol 198:2575-2580.

Johnson BG, Wright RA, Arnold MB, Wheeler WJ, Ornstein PL, Schoepp DD (1999) [3H]-LY341495 as a novel antagonist radioligand for group II metabotropic glutamate ( $\mathrm{mGlu}$ ) receptors: characterization of binding to membranes of mGlu receptor subtype expressing cells. Neuropharmacology 38:1519-1529.

Kingston AE, Ornstein PL, Wright RA, Johnson BG, Mayne NG, Burnett JP, Belagaje R, Wu S, Schoepp DD (1998) LY341495 is a nanomolar potent and selective antagonist of group II metabotropic glutamate receptors. Neuropharmacology 37:1-12.

Koh JY, Suh SW, Gwag BJ, He YY, Hsu CY, Choi DW (1996) The role of zinc in selective neuronal death after transient global cerebral ischemia. Science 272:1013-1016.

Krieger P, El Manira A (2002) Group III mGluR-mediated depression of sensory synaptic transmission. Brain Res 937:41-44.

Lam AG, Soriano MA, Monn JA, Schoepp DD, Lodge D, Mc Culloch J (1998) Effects of the selective metabotropic glutamate agonist LY354740 in a rat model of permanent ischaemia. Neurosci Lett 254:121-123.

Lee JM, Zipfol GJ, Choi DW (1999) The changing landscape of ischaemic brain injury mechanisms. Nature 24:A7-A14.

Linn CL (2000) Second messenger pathways involved in up-regulation of an L-type calcium channels. Vis Neurosci 17:473-482.

Linn CL, Gafka AC (1999) Activation of metabotropic glutamate receptor modulates the voltage-gated sustained calcium currents in a teleost horizontal cell. J Neurophysiol 81:425-434.

Lucchi R, Poli A, Traversa U, Barnabei S (1994) Functional adenosine A1 receptors in goldfish brain: regional deistribution and inhibition of $\mathrm{K}^{+}$-evoked glutamate release from cerebellar slices. Neuroscience 58:237-243.

Lutz PL (1992) Mechanisms for anoxic survival in the vertebrate brain. Annu Rev Physiol 54:601-618.

Lutz PL, Nilsson GE, Perez-Pinzon MA (1996) Anoxia tolerant animals from a neurobiological perspective. Comp Biochem Physiol B Biochem Mol Biol 113:3-13.

Medler KF, Tran HN, Parker JM, Caprio J, Bruch RC (1998) Metabotropic glutamate receptor expression in olfactory receptor neurons from the channel catfish, Ictalurus punctatus. J Neurobiol 35:94-104.

Meli E, Picca R, Attucci S, Cozzi A, Peruginelli F, Moroni F, PellegriniGiampietro D (2002) Activation of mGlul but not mGlu5 metabotropic glutamate receptors contributes to postischemic neuronal injury in vitro and in vivo. Pharmacol Biochem Behav 73:439-446.

Monn JA, Valli MJ, Massey SM, Hansen MM, Kress TJ, Wepsiec JP, Harkness AR, Grutsch Jr JL, Wright RA, Johnson BG, Andis SL, Kingston A, Tomlinson R, Lewi SR, Griffey KR, Tizzano JP, Schoepp DD (1999) Synthesis, pharmacological characterization, and molecular modeling of heterobicyclic amino acids related to (+)-2-aminobicyclo[3.1.0] hexane-2, 6-dicarboxylic acid (LY354740): identification of two new potent, selective, and systemically active agonists for group II metabotropic glutamate receptors. J Med Chem 42:1027-1040.

Moroni F, Attucci S, Cozzi A, Meli E, Picca R, Scheideler MA, Pellicciari R, Noe C, Sarichelou I, Pellegrini-Giampietro D (2002) The novel and systemically active metabotropic glutamate 1 (mGlu1) receptor antagonist 3-MATIDA reduces post-ischemic neuronal death. Neuropharmacology 42:741-751.

Nicoletti F, Bruno V, Copani A, Casabona G, Knopfel T (1996) Metabotropic glutamate receptors: a new target for the therapy of neurodegenerative disorders? Trends Neurosci 19:267-271.

Nilsson GE, Perez-Pinzon M, Dimberg K, Winberg S (1993) Brain sensitivity to anoxia in fish as reflected by changes in extracellular $\mathrm{K}+$ activity. Am J Physiol 264:R250-R253.

Ornstein PL, Arnold MB, Bleisch TJ, Wright RA, Wheeler WJ, Schoepp DD (1998) [3H]LY341495, a highly potent, selective and novel radioligand for labeling group II metabotropic glutamate receptors. Bioorg Med Chem Lett 8:1919-1922.

Pellegrini-Giampietro D, Peruginelli F, Meli E, Cozzi A, Albani-Torregrossa S, Pellicciari R, Moroni F (1999a) Protection with metabotropic glutamate 1 receptor antagonists in models of ischemic neuronal death: timecourse and mechanisms. Neuropharmacology 38:1607-1619.

Pellegrini-Giampietro D, Cozzi A, Peruginelli F, Leonardi P, Meli E, Pellicciari R, Moroni F (1999b) 1-Aminoindan-1, 5-dicarboxylic acid and (S)-(+)-2-(3'-carboxybicyclo[1.1.1] pentyl)-glycine, two mGlu1 receptor-preferring antagonists, reduce neuronal death in in vitro and in vivo models of cerebral ischaemia. Eur J Neurosci 11:3637-3647.

Pin JP, Duvoisin R (1995) The metabotropic glutamate receptors: structure and functions. Neuropharmacology 34:1-26.

Poli A, Notari S, Virgili M, Fabbri E, Lucchi R (1997) Neurochemical changes in cerebellum of goldfish exposed to various temperatures. Neurochem Res 22:141-149.

Poli A, Lucchi R, Storto M, De Paolis P, Notari S, Nicoletti F, Casabona G (1999) Predominant expression of group-II metabotropic glutamate receptors in the goldfish brain. Brain Res 10:142-145.

Rao AM, Hatcher JF, Dempsey RJ (2000) Neuroprotection by group I 
metabotropic glutamate receptor antagonists in forebrain ischemia of gerbil. Neurosci Lett 20:1-4.

Rosati AM, Traversa U, Lucchi R, Poli A (1995) Biochemical and pharmacological evidence for the presence of A1 but not A2A adenosine receptors in the brain of the low vertebrate teleost Carassius auratus (goldfish). Neurochem Int 26:411-423.

Schoepp DD, Jane DE, Monn JA (1999) Pharmacological agents acting at subtypes of metabotropic glutamate receptors. Neuropharmacology 38:1431-1476.

Shiells RA, Falk G (2000) Activation of $\mathrm{Ca}^{2+}$-calmodulin kinase II induces desensitization by background light in dogfish retinal 'on' bipolar cells. J Physiol (Lond) 528:327-338.

Smith RW, Houlihan DF, Nilsson GE, Brechin JG (1996) Tissue-specific changes in protein synthesis rates in vivo during anoxia in crucian carp. Am J Physiol 271:R897-R904.

Tamaru Y, Nomura S, Mizuno N, Shigemoto R (2001) Distribution of metabotropic glutamate receptor mGlu3 in the mouse CNS: differential location relative to pre- and postsyanptic sites. Neuroscience 106:481-503.

Yamada M, Fraser SP, Furukawa T, Hirasawa H, Katano K, Djamgoz M, Yasui S (1999) Effects of nitric oxide, light adaptation and APB on spectral characteristics of $\mathrm{H} 1$ horizontal cells in carp retina. Neurosci. Res 35:309-319.

Zhang C, Schmidt JT (1999) Adenosine A1 and class II metabotropic glutamate receptors mediate shared presynaptic inhibition of retinotectal transmission. J Neurophysiol 82:2247-2255. 